\title{
Correction: Somatic mutations in cancer development
}

\author{
Lucio Luzzatto \\ From First Lorenzo Tomatis Conference on Environment and Cancer \\ Turin, Italy. 4-5 June 2009
}

\begin{abstract}
Since publication of Environmental Health 2011, 10(Suppl 1):S12 [1] it has been noticed that titles and captions for the figures and tables were incorrectly applied. In this full-length correction article, figures and tables have been renumbered with legends and captions applied appropriately. Some minor typographical errors have also been corrected. The inconvenience caused to readers by premature publication of the original paper is regretted.

The transformation of a normal cell into a cancer cell takes place through a sequence of a small number of discrete genetic events, somatic mutations: thus, cancer can be regarded properly as a genetic disease of somatic cells. The analogy between evolution of organisms and evolution of cell populations is compelling: in both cases what drives change is mutation, but it is Darwinian selection that enables clones that have a growth advantage to expand, thus providing a larger target size for the next mutation to hit. The search for molecular lesions in tumors has taken on a new dimension thanks to two powerful technologies: the micro-arrays for quantitative analysis of global gene expresssion (the transcriptome); and 'deep' sequencing for the global analysis of the entire genome (or at least the exome). The former offers the most complete phenotypic characterization of a tumor we could ever hope for - we could call this the ultimate phenotype; the latter can identify all the somatic mutations in an individual tumor - we could call this the somatic genotype. However, there is definitely the risk that while we are 'drowned by data, we remain thirsty for knowledge'. If we want to heed the teachings of Lorenzo Tomatis, I think the message is clear: we ought to take advantage of the new powerful technologies - not by becoming their slaves, but remaining their masters. Identifying somatic mutations in a tumor is important because through a deeper understanding of the nature of that particular tumor it can help us to optimize therapy or to design new therapeutic approaches.
\end{abstract}

\section{Introduction}

Lorenzo Tomatis was a towering figure in the study of cancer and cancer epidemiology: not just because from 1982 to 1993 he was the Director of the International Agency for Research against Cancer (IARC), but even more because he commanded immense international respect as a scientist ahead of his time in the understanding of the environmental causes of cancer. Tomatis' major influence in this area spanned some four decades [2,3] (see Figs. 1a and 1b). I never worked with Renzo, but I have vivid memories of many encounters and discussions I had with him, both about science and

Correspondence: lucio.luzzatto@ittumori.it

Scientific Director, Istituto Toscano Tumori, Florence, Italy about research policies: and I am forever grateful for what I learnt from him.

My job today is to discuss the role of somatic mutations in oncogenesis. In a nutshell, and using a timehonoured terminology of medicine, if heredity and environment are the aetiology of cancer, somatic mutations are the essence of its pathogenesis. With respect to heredity, it is abundantly clear that one never does inherit cancer, but rather one may inherit an increased risk of cancer [4]. In first approximation, some mutant genes entail a very high risk of cancer, so much so that they behave as Mendelian dominants (see Fig. 2), and they are therefore called high penetrance (cancer susceptibility) genes. These include (i) tumor suppressors (e.g. p53, APC, GPC3, VHL, CDKN2A, MEN1), (ii)

\section{Biomed Central}




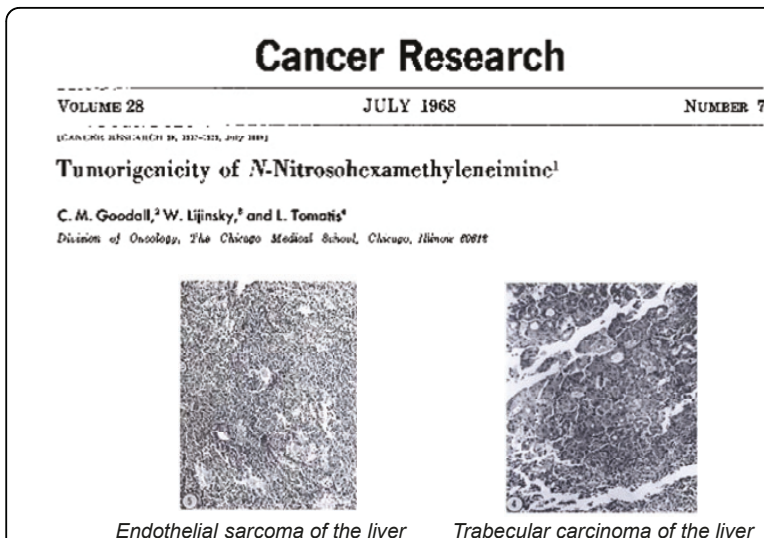

Fig 1a

ANN IST SUPER SANITÀ 2006 | VOL. 42, NO. 2: 113-117 113

Role of experimental and epidemiological evidence of carcinogenicity in the primary prevention of cancer

Lorenzo Tomatis International Society of Doctors for the Environment (ISDE), Trieste, Italy

Fig $1 b$

Figure 1 Headings of one of the first and one of the last publications by Lorenzo Tomatis.

oncogenes (e.g. PDGFRA, KIT, MET, RET), and (iii) genes required for genome stability (e.g. $A T M, B L M$, FANCA, BRCA2, MSH2, XPA). Known high penetrance genes number by now several dozens [5]: they may have tumor (site) specificity (e.g. BRCA2) or they may not (e.g. p53). In addition, numerous clinical observations (see for instance Fig. 3 [6]) indicate that cancer susceptibility may 'run in families' in a more subtle way, and this has led to the notion of low penetrance (cancer susceptibility) genes [7]. These are important because they may contribute significantly to the cancer burden in a population (see Table 1). Until recently, candidate low penetrance genes have been chased through (i) tests on first degree relatives [8], (ii) kinship analysis [9], (iii) studies on twins [10], and (iv) linkage disequilibrium analysis in appropriate populations [11-13] It must be admitted that until recently the yield has been limited, although individual examples have turned up, for instance among genes involved in signal transduction pathways (e.g. the TGF $\beta$ receptor: see Fig. 4), and numerous genes involved in DNA repair (Table 2). Over the past 4 years, however, genome-wide association studies (GWAS) have become very popular: this is not a conceptually new approach, as it is merely an updated version of (iv), but it is made much more powerful through the availability of some millions single nucleotide polymorphisms (SNPs). Thanks to this increased power, many low penetrance genes or loci have been now identified, that affect the risk of individual types (or several types) of cancer - mostly by less than $+/-30 \%-$ in one or another population (see 40 references in webappendix of recent paper by Hartman et al.[14] .

With respect to the environment, I think the most lasting monumental memorial to Lorenzo is the series of IARC publications on carcinogenic agents which, in the jargon of the cognoscentes, are known simply as The Monographs. Rarely has an international agency been able to generate publications (each one the product of a collegial effort) with so much scientific content; even more rarely has this taken place consistently in dozens of volumes over some thirty years, to the extent that the Monographs are universally regarded as the ultimate authority on their individual topics; and probably never has a single person - namely Tomatis himself - through his scientific rigor, his incredible dedication, and his unique ability to catalyze consensus whenever possible, contributed so much to a successful venture of this nature.

The model of oncogenesis pioneered by John Cairns [15] contained already the key for reconciling aetiology and pathogenesis. The transformation of a normal cell into a cancer cell takes place through a sequence of a small number of discrete genetic events, somatic mutations (Figure 5): thus, cancer can be regarded properly as a genetic disease of somatic cells $[4,16]$. The analogy between evolution of organisms and evolution of cell populations is compelling (Table 3): in both cases what drives change is mutation, but it is Darwinian selection that enables clones that have a growth advantage to expand, thus providing a larger target size for the next mutation to hit $[15,17,18]$ (Figure 5). This model offers a simple interpretation to the mechanism of action of the aetiological factors we have mentioned. An environmental agent can increase the rate of somatic mutation (i.e., it may be mutagenic, like ionizing radiation), or it can increase the rate of cell proliferation (as when Helicobacter pylori causes gastritis), or it may do both things (this is probably the case with the hepatitis B virus causing hepatoma). As for heredity, in the majority of cases it acts probably by increasing the mutation rate, and this may apply to both high penetrance genes and to low penetrance genes; on the other hand, sometimes an 


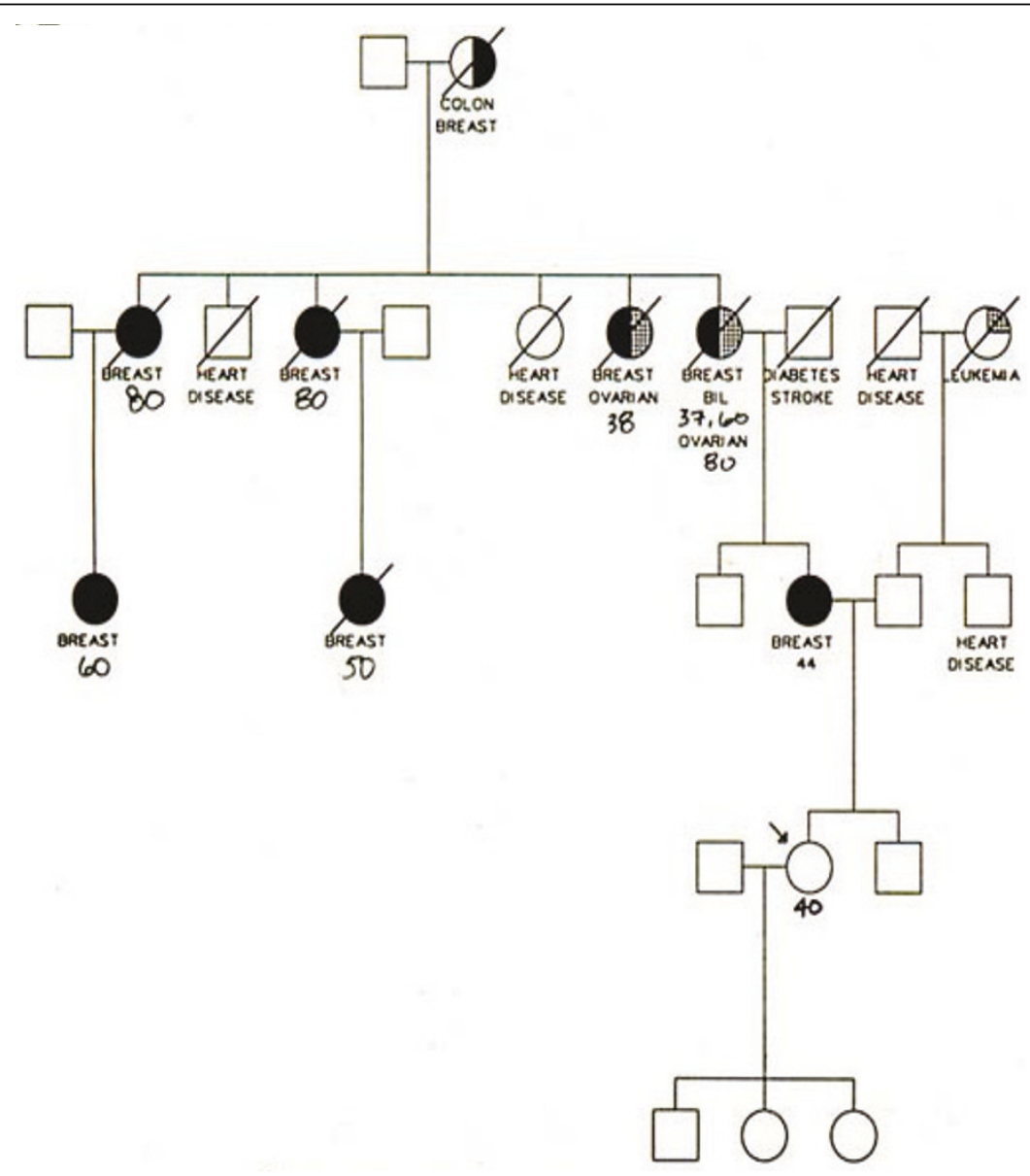

Figure 2 Pedigree of a family with a high rate of breast cancer and ovarian cancer: the increased tendency to developing cancer shows a Mendelian autosomal dominant pattern of inheritance, suggesting that a single gene is largely responsible.

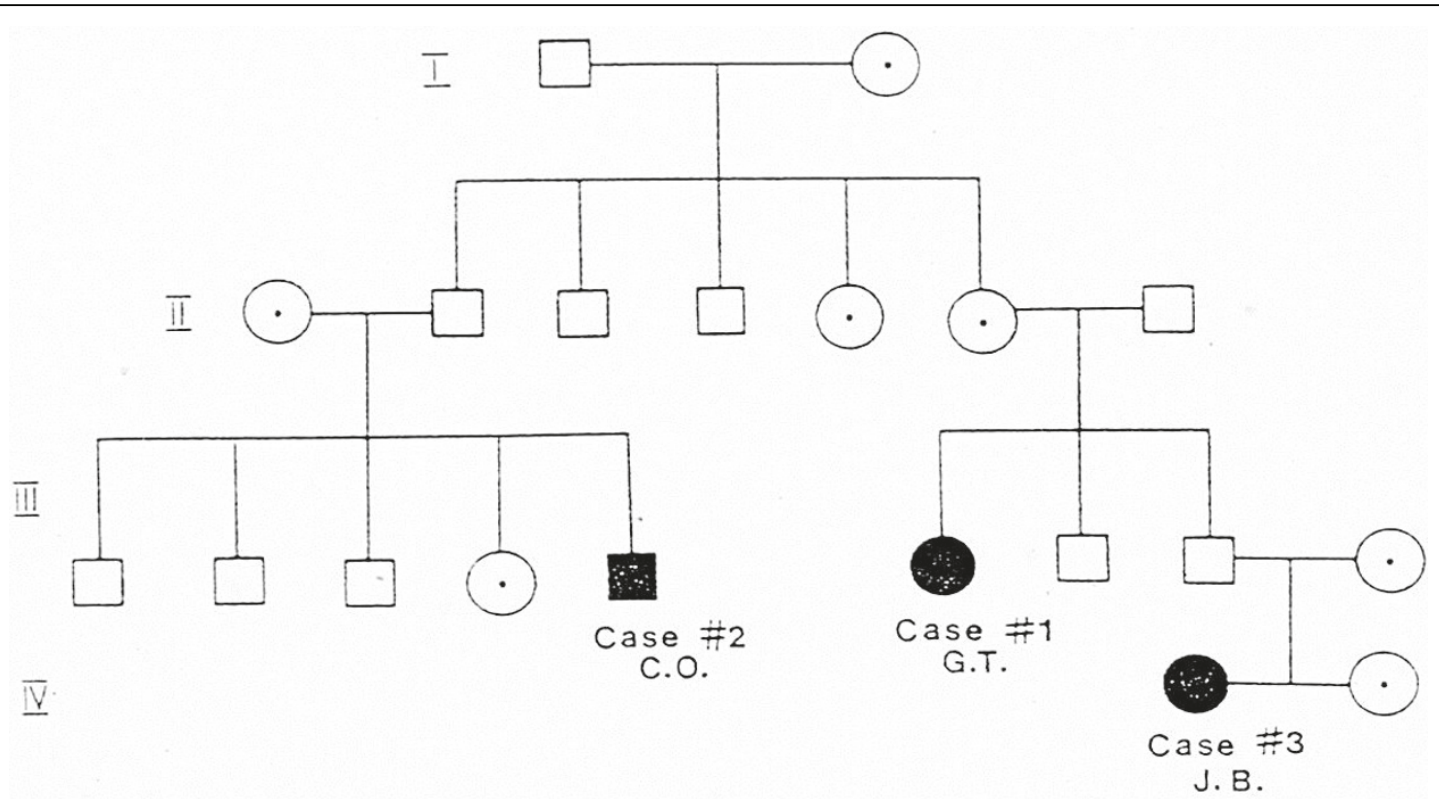

Figure 3 In this extended family there were $\mathbf{3}$ cases of hairy cell leukaemia $(\mathbf{H C L})$ : their co-existence can be hardly a coincidence, since $\mathrm{HCL}$ is one of the rarest forms of B cell leukaemia. Here the pattern is not Mendelian, suggesting that several genes and/or environmental factors are involved (from ref. [6]). 
Table 1 Two types of cancer genes

\begin{tabular}{lcc}
\hline & "Strong" & "Weak" \\
\hline Penetrance & High & Low \\
Population frequency & Low & May be high \\
Detectable by linkage analysis & Yes & No \\
Detectable by LD analysis & Difficult & Possible \\
Examples & Rb, BRCA1 & MDM2, TGFRB \\
Overall contribution to cancer prevalence & Low & Could be high \\
\hline
\end{tabular}

oncogene with a germ-line mutation appears to be in lieu of the first somatic mutation, for instance in the case of RET in Multiple Endocrine Neoplasia type 2, thus decreasing by one the number of mutations required for the development of cancer (see Figure 6).

In order to understand the pathogenesis of tumors we must consider their very extensive variety: not only can they arise in virtually every possible cell type in the body, but even within the set of tumors arising from a specific type of cell there is marked heterogeneity, some of it well explored and some yet to be unravelled. The somatic mutation-Darwinian selection model of cancer is appropriately versatile: we can presume, and we know in specific cases that different genes are involved: some 400 have been already identified [19]. To this end, the methodology that has given the highest returns has been cytogenetic analysis, which has spotted (i) chromosomal translocations harbouring fusion genes or rearrangements that dysregulate gene expression, as well as (ii)
Table 2 Several low penetrance cancer genes are those involved in DNA repair. From Vineis et al. [38]

\begin{tabular}{lll}
\hline Gene & $\boldsymbol{N}$ studies & Type of tumor(s) \\
\hline BRCA2 & 2 & Breast \\
CCND1 & 2 & Head \& Neck \\
ERCC1 & 2 & Bladder \\
ERCC2 & 53 & Bladder; lung \\
ERCC4 & 6 & Breast \\
ERCC5 & 2 & Lung \\
MGMT & 2 & Prostate \\
NBN & 4 & Bladder \\
PARP1 & 2 & Breast \\
POLI & 3 & Lung \\
TP53 & 115 & Breast;cervix;lung \\
XPA & 8 & Lung \\
XRCC1 & 21 & Cervix; esophageal, head \& neck; skin; stomach \\
XRCC2 & 2 & Colorectal \\
XRCC3 & 37 & Breast; stomach \\
XRCC4 & 2 & Bladder \\
\hline
\end{tabular}

loss of heterozigosity betraying deletions. In other cases somatic mutations have been discovered in genes already known to have germ-line mutations in cancerprone families, or by deliberately testing for somatic mutations in candidate genes. Not surprisingly, many of the genes involved belong to sets that are relevant to broad functions within the cell (the buzz-term today is gene ontology): particularly the cell cycle, signalling,

All Cancers: ${ }^{*} 6 \mathrm{~A}{ }^{*} 9 \mathrm{~A}$ or ${ }^{*} 6 \mathrm{~A}^{*} 6 \mathrm{~A}$

Citation

Pasche US 1999

Tilborg 2001

Baxter 2002

Chen 1999

Samowitz 2001

Pasche Italy 1999

Stefanovska_letter 2001

Overall (7)
Cases Controls

$\begin{array}{cc}141 / 1702 & 78 / 1470 \\ 25 / 292 & 38 / 366 \\ 165 / 1318 & 43 / 496 \\ 12 / 132 & 7 / 136 \\ 50 / 504 & 68 / 724 \\ 53 / 694 & 12 / 100 \\ 10 / 234 & 22 / 400 \\ 456 / 4876 & 268 / 3692\end{array}$

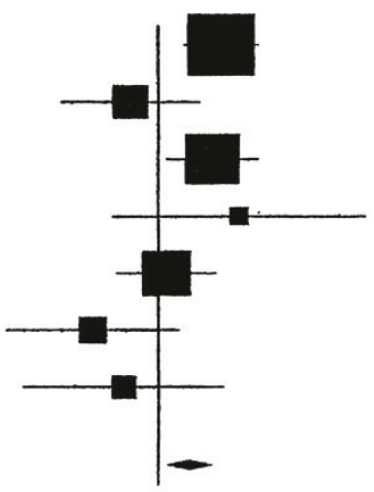

$\begin{array}{llllll}0.1 & 0.2 & 0.5 & 1 & 2 & 5\end{array}$

510

more in controls more in cases

Figure 4 Meta-analysis of the quantitative effect of a polymorphic allele of the TGF $\beta$ receptor gene on the frequency of some types of tumors. (from ref. [39]) 


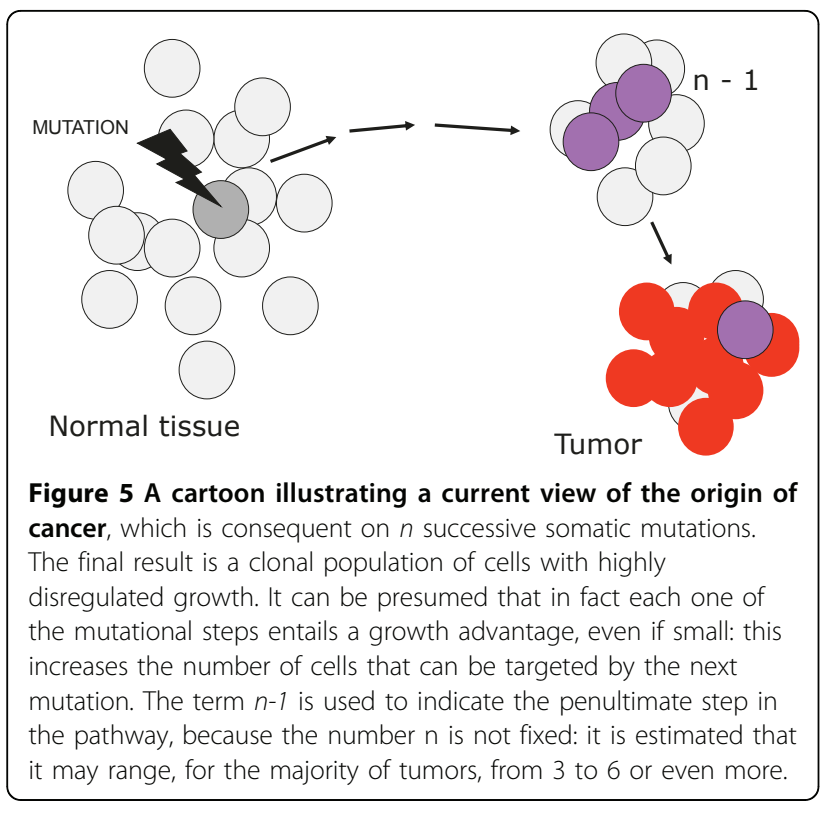

regulation of transcription, apoptosis and, once again, genome stability (DNA repair) [20,21].

The search for molecular lesions in tumors has taken on a new dimension thanks to two powerful technologies: the micro-arrays for quantitative analysis of global gene expression [22-26] (the transcriptome); and 'deep' sequencing for the global analysis of the entire genome (or at least the exome). The former offers the most complete phenotypic characterization of a tumor we could ever hope for - we could call this the ultimate phenotype; the latter can identify all the somatic mutations in an individual tumor - we could call this the somatic genotype (see Figure 7). The ground-breaking paper [27] on the latter was published in 2006; and already it has been followed by a flurry of similar work on different types of tumors [28-31]. The somatic genotype of the tumor can be fully characterized by sequencing in parallel (from non-tumor DNA) also the inherited genome of the patient: thus, the issue of inherited variation versus acquired somatic mutation can be rigorously circumvented. A more difficult issue has to do with the fact that somatic mutations can occur (indeed are relatively common) in any normal cell: therefore a somatic mutation found in a tumor does non automatically qualify as

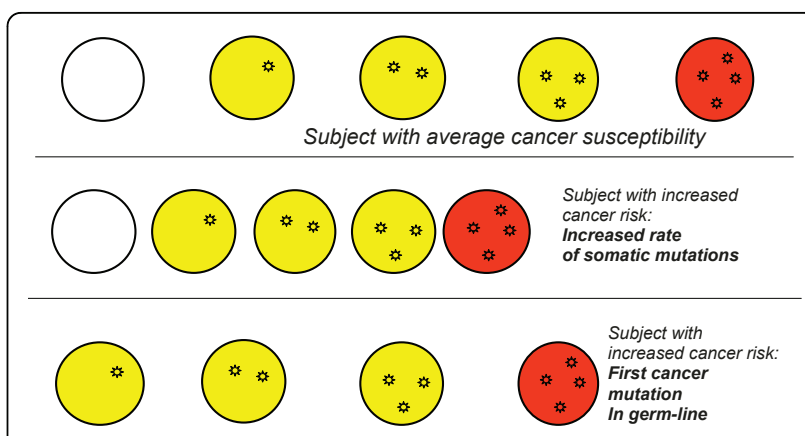

Figure 6 Inherited mutations can increase cancer proneness through different mechanisms. The top section of the cartoon is a schematic of the process outlined in Fig. 5. The middle section illustrates how an increased rate of somatic mutations can produce an accelerated rate of the oncogenic pathway: this is the case for instance for patients with Fanconi anemia, who have a serious defect in DNA repair and often develop cancer at a young age. The bottom section illustrates that the number of steps for a normal cell to become a cancer cell is cut by one if the first mutation is an inherited (germ-line) mutation rather than an acquired somatic mutation: this is the case for instance for patients who have an APC mutation and present with familial adenomatous polyposis.

being causative of that tumor; therefore we must improve algorithms aiming to disentangle driver mutations (i.e. pathogenic mutations) from passenger mutations. At any rate, by this approach not only are new genes being identified; also, patterns of mutations are emerging (Table 4) that may be signatures of exposure to individual environmental mutagens [27]: an unexpected bonus of molecular studies that is highly relevant to the focus of this meeting.

Somatic mutations are central to the process of oncogenesis, because almost certainly no tumor can arise without them (although epigenetic phenomena are important [32-34], I think it is highly unlikely that gene silencing by promoter methylation alone can do the job). The rate of somatic mutations - and thus the risk of cancer - can be increased by inherited genes or by environmental agents, as we have outlined; however, somatic mutations occur all the time as spontaneous stochastic events, because the replication of DNA is extremely faithful but not perfect: this means that there is always an element of chance in oncogenesis (Figure 8). In this respect, we know surprisingly little about the

Table 3 The principles and theory of population genetics can be applied to populations of cells.

\begin{tabular}{lll}
\hline Events/processes & In populations of organisms & In populations of somatic cells \\
\hline Mutation & Creates a mutant individual/family & Creates a mutant cell/clone \\
Lethal mutation & No offspring & No clonal growth \\
Neutral mutation & No visible change & No visible change \\
Mutation with absolute advantage & Mutant people will gradually take over & Clone will grow faster than other cells \\
Mutation with conditional advantage & Mutant people will increase in a certain environment & Clone will grow faster under certain conditions \\
\hline
\end{tabular}




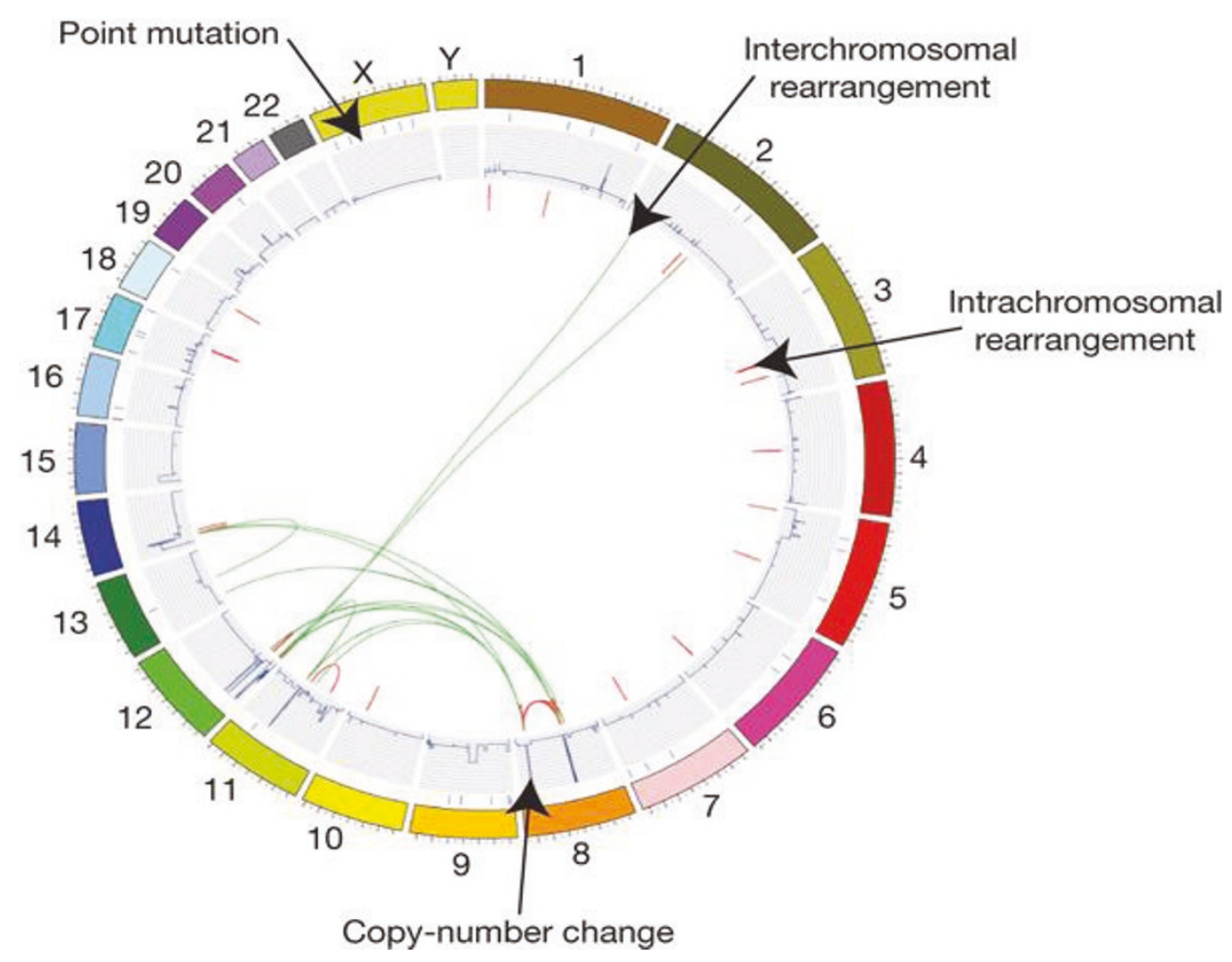

Figure $7 \mathrm{~A}$ graphic representation (currently referred to as a cyclo-plot) of the multiple defects detected in the genome of a tumor (a small-cell lung cancer cell line) by deep sequencing. Individual chromosomes are depicted on the outer circle followed by concentric tracks for point mutation, copy number and rearrangement data relative to mapping position in the genome. Arrows indicate examples of the various types of somatic mutation present in this cancer genome. From Stratton et al., 2009 (from ref. [30]).

normal baseline somatic mutation rate $(\mu)$. Over the past several years, by using the $\mathrm{X}$-linked gene PIG- $A$ as a sentinel gene, we have developed a relatively simple methodology to measure $\mu$ in any individual [35-37]: we have determined the normal range of $\mu$, and we have shown that it is higher in several groups of cancerprone subjects (see Figure 9) It will be important to determine whether $\mu$ correlates with the risk of sporadic cancer, and whether we can measure changes in $\mu$ in subjects who are exposed to environmental carcinogens. It is also not unconceivable that $\mu$ could be decreased by pharmacological agents.

The progress of contemporary biology has led us within thirty years from a multitude of theories about oncogenesis to the established fact that cancer is a genetic disorder of somatic cells. On the other hand, much recent literature gives the impression that there is a surplus of information, from gene expression profiles

Table 4 Some specific types of somatic mutations found in tumors. From Sjoblom et al., [27].

\begin{tabular}{|c|c|c|c|c|}
\hline & & COLON & BREAST & TOTAL \\
\hline \multirow[t]{3}{*}{ Substitutions at CG base pairs } & CG to TA & $413(\mathbf{5 9 . 3})$ & $289(34.5)$ & $702(45.8)$ \\
\hline & CG to GC & $48(6.9)$ & $239(\mathbf{2 8 . 5})$ & $287(18.7)$ \\
\hline & CG to AT & $93(13.4)$ & $148(17.7)$ & $241(15.7)$ \\
\hline \multirow[t]{3}{*}{ Substitutions at TA base pairs } & TA to $C G$ & $56(8.0)$ & $72(8.6)$ & $128(8.3)$ \\
\hline & TA to GC & $51(7.3)$ & $35(4.2)$ & $86(5.6)$ \\
\hline & TA to AT & $35(5.0)$ & $55(6.6)$ & $90(5.9)$ \\
\hline \multirow[t]{2}{*}{ Substitutions at specific dinucleotides } & $5^{\prime}-\mathrm{CpG}-3^{\prime}$ & $309(\mathbf{4 4 . 4})$ & $139(\mathbf{1 6 . 6})$ & $448(29.2)$ \\
\hline & $5^{\prime}-T p C-3^{\prime}$ & $79(11.4)$ & $257(30.7)$ & $336(21.9)$ \\
\hline TOTAL & & 696 & 838 & 1534 \\
\hline
\end{tabular}




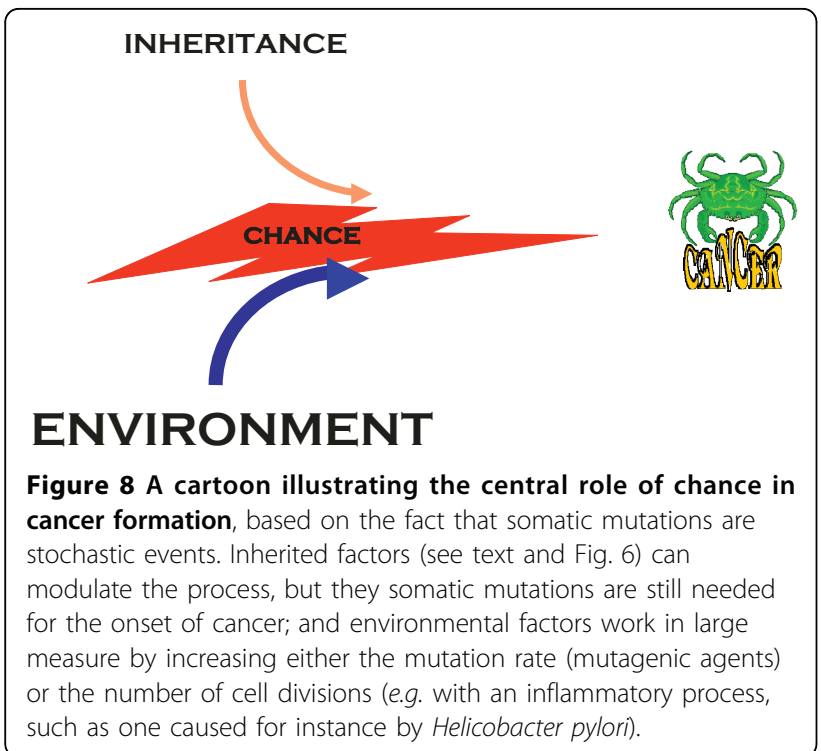

to proteomics to metabolomics, with the risk that while we are truly 'drowned by data, we remain thirsty for knowledge'. If we want to heed the teachings of Lorenzo Tomatis, I think the message is clear: we ought to take advantage of the new powerful technologies - not by becoming their slaves, but remaining their masters. Identifying somatic mutations in a tumor is important not because it qualifies for 'oncogenomics', but because through a deeper understanding of the nature of that particular tumor it can help us to optimize therapy or to design new therapeutic approaches.

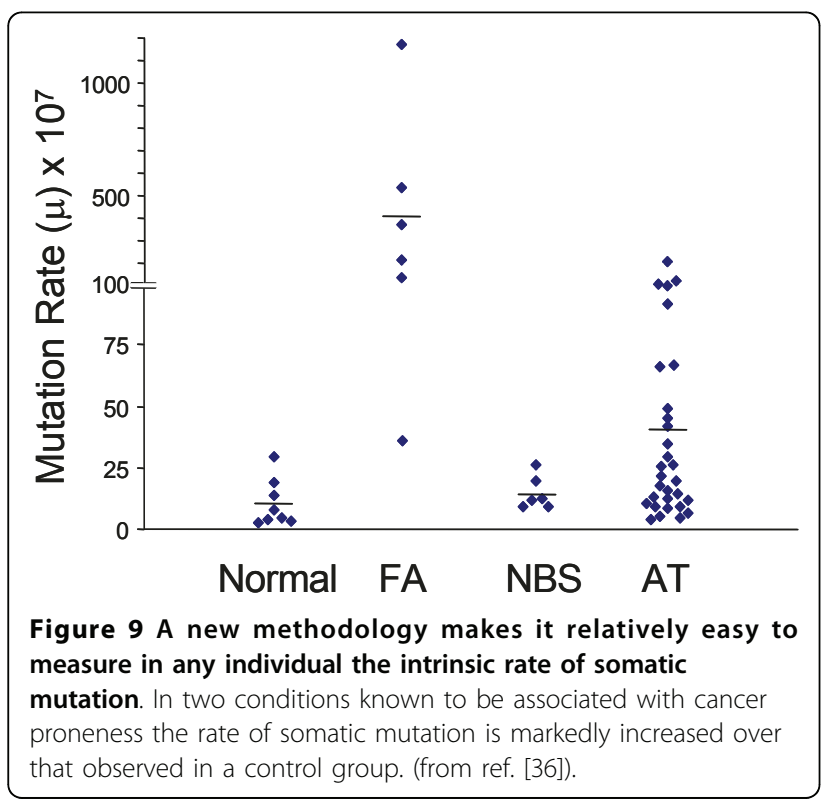

\section{Acknowledgements}

This article has been published as part of Environmental Health Volume 10 Supplement 1, 2011: Proceedings of the First Lorenzo Tomatis Conference on Environment and Cancer. The full contents of the supplement are available online at http://www.ehjournal.net/supplements/10/S1.

\section{Competing interests}

The author declares that he has no competing financial or non-financial interests.

Published: 28 July 2011

\section{References}

1. Luzzatto L: Somatic mutations in cancer development. Environmental Health 2011, 10(Suppl 1):S12

2. Lijinsky W, Lee KY, Tomatis L, Buutler WH: Nitrosoazetidine-a potent carcinogen of low toxicity. Die Naturwissenschaften 1967, 54(19):518.

3. Tomatis $L$ : Identification of carcinogenic agents and primary prevention of cancer. Ann N Y Acad Sci 2006, 1076:1-14.

4. Vogelstein BaK KW: The Genetic Basis of Human Cancer. New York: McGraw-Hill; 22002.

5. Offit K: Clinical cancer genetics: risk counseling and management. New York: Wiley-Liss; 19981.

6. Gramatovici M, Bennett JM, Hiscock JG, Grewal KS: Three cases of familial hairy cell leukemia. Am J Hematol 1993, 42(4):337-339.

7. Fraumeni JF Jr.: Epidemiologic approaches to cancer etiology. Annu Rev Public Health 1982, 3:85-100.

8. Narod SA, Stiller C, Lenoir GM: An estimate of the heritable fraction of childhood cancer. Br J Cancer 1991, 63:993-999.

9. Cannon-Albright LA, Thomas A, Goldgar DE, Gholami K, Rowe K, Jacobsen M, McWhorter WP, Skolnick MH: Familiality of cancer in Utah. Cancer Res 1994, 54(9):2378-2385.

10. Kadan-Lottick NS, Kawashima T, Tomlinson G, Friedman DL, Yasui $Y$, Mertens AC, Robison LL, Strong LC: The risk of cancer in twins: a report from the childhood cancer survivor study. Pediatr Blood Cancer 2006, 46(4):476-481.

11. Stephens JC, Briscoe D, O'Brien SJ: Mapping by admixture linkage disequilibrium in human populations: limits and guidelines. Am J Hum Gene 1994, 55(4):809-824.

12. Weber $B L$, Nathanson KL: Low penetrance genes associated with increased risk for breast cancer. Eur J Cancer 2000, 36(10):1193.

13. Nathanson $\mathrm{KL}$, Wooster $\mathrm{R}$, Weber $\mathrm{BL}$ : Breast cancer genetics: what we know and what we need. Nat Med 2001, 7(5):552-556.

14. Hartman M, Loy EY, Ku CS, Chia KS: Molecular epidemiology and its current clinical use in cancer management. Lancet Oncol 2010, 11(4):383-390.

15. Cairns J: Mutation selection and the natural history of cancer. Nature 1975, 255(5505):197-200.

16. Luzzatto L, Pandolfi PP: Laukaemia: a genetic disorder of haemopoietic cells. BMJ 1993, 307:579-580

17. Cahill DP, Kinzler KW, Vogelstein B, Lengauer C: Genetic instability and darwinian selection in tumours. Trends Cell Biol 1999, 9(12):M57-60

18. Greaves M: Darwinian medicine: a case for cancer. Nature Reviews 2007 7(3):213-221.

19. Futreal PA, Coin L, Marshall M, Down T, Hubbard T, Wooster R, Rahman N, Stratton MR: A census of human cancer genes. Nature Reviews 2004, 4(3):177-183.

20. Hanahan D, Weinberg RA: The hallmarks of cancer. Cell 2000, 100(1):57-70.

21. Vogelstein B, Kinzler KW: Cancer genes and the pathways they control. Nat Medicine 2004, 10(8):789-799.

22. van 't Veer LJ, Dai $H$, van de Vijver MJ, He YD, Hart AA, Mao M, Peterse $H L$, van der Kooy K, Marton MJ, Witteveen AT, et al: Gene expression profiling predicts clinical outcome of breast cancer. Nature 2002, 415(6871):530-536

23. Ma XJ, Wang Z, Ryan PD, Isakoff SJ, Barmettler A, Fuller A, Muir B, Mohapatra G, Salunga R, Tuggle JT, et al: A two-gene expression ratio predicts clinical outcome in breast cancer patients treated with tamoxifen. Cancer cell 2004, 5(6):607-616.

24. Nelson PS: Predicting prostate cancer behavior using transcript profiles. Urol 2004, 172(5 Pt 2):S28-32, discussion S33. 
25. Sotiriou C, Pusztai L: Gene-expression signatures in breast cancer. NEJM 2009, 360(8):790-800

26. Cavalieri D, Dolara P, Mini E, Luceri C, Castagnini C, Toti S, Maciag K, De Filippo C, Nobili S, Morganti M, et al: Analysis of gene expression profiles reveals novel correlations with the clinical course of colorectal cancer. Oncol Res 2007, 16(11):535-548.

27. Sjoblom T, Jones S, Wood LD, Parsons DW, Lin J, Barber TD, Mandelker D, Leary RJ, Ptak J, Silliman N, et al: The Consensus Coding Sequences of Human Breast and Colorectal Cancers. Science 2006, 314(5797):268-274.

28. Mardis ER, Ding L, Dooling DJ, Larson DE, McLellan MD, Chen K, Koboldt DC, Fulton RS, Delehaunty KD, McGrath SD, et al: Recurring mutations found by sequencing an acute myeloid leukemia genome. NEJM 2009, 361(11):1058-1066.

29. Weir BA, Woo MS, Getz G, Perner S, Ding L, Beroukhim R, Lin WM, Province MA, Kraja A, Johnson LA, et al: Characterizing the cancer genome in lung adenocarcinoma. Nature 2007, 450(7171):893-898,

30. Stratton MR, Campbell PJ, Futreal PA: The cancer genome. Nature 2009, 458(7239):719-724.

31. Ley TJ, Mardis ER, Ding L, Fulton B, McLellan MD, Chen K, Dooling D, Dunford-Shore BH, McGrath S, Hickenbotham M, et al: DNA sequencing of a cytogenetically normal acute myeloid leukaemia genome. Nature 2008, 456(7218):66-72.

32. Esteller M: Epigenetics provides a new generation of oncogenes and tumour-suppressor genes. BrJ Cancer 2006, 94(2):179-183.

33. Fraga MF, Esteller M: Towards the human cancer epigenome: a first draft of histone modifications. Cell cycle (Georgetown, Tex 2005, 4(10):1377-1381.

34. McKenna ES, Roberts CW: Epigenetics and cancer without genomic instability. Cell cycle (Georgetown, Tex 2009, 8(1):23-26.

35. Araten DJ, Nafa K, Pakdeesuwan K, Luzzatto L: Clonal populations of hematopoietic cells with paroxysmal nocturnal hemoglobinuria genotype and phenotype are present in normal individuals. Proc Natl Acad Sci U S A 1999, 96(9):5209-5214.

36. Araten DJ, Golde DW, Zhang RH, Thaler HT, Gargiulo L, Notaro R, Luzzatto L: A Quantitative Measurement of the Human Somatic Mutation Rate. Cancer Res 2005, 65(18):8111-8117.

37. Peruzzi $B$, Araten DJ, Notaro R, Luzzatto L: The use of PIG-A as a sentinel gene for the study of the somatic mutation rate and of mutagenic agents in vivo. Mutat Res 2010, 705(1):3-10

38. Vineis $P$, Manuguerra M, Kavvoura FK, Guarrera S, Allione A, Rosa F, Di Gregorio A, Polidoro S, Saletta F, loannidis JP, Matullo G: A field synopsis on low-penetrance variants in DNA repair genes and cancer susceptibility. J Natl Cancer Inst 2009, 101(1):24-36.

39. Kaklamani VG, Hou N, Bian Y, Reich J, Offit K, Michel LS, Rubinstein WS, Rademaker A, Pasche B: TGFBR1*6A and cancer risk: a meta-analysis of seven case-control studies. J Clin Oncol 2003, 21(17):3236-43.

doi:10.1186/1476-069X-10-S1-S16

Cite this article as: Luzzatto: Correction: Somatic mutations in cancer development. Environmental Health 2011 10(Suppl 1):S16.

\section{Submit your next manuscript to BioMed Central and take full advantage of:}

- Convenient online submission

- Thorough peer review

- No space constraints or color figure charges

- Immediate publication on acceptance

- Inclusion in PubMed, CAS, Scopus and Google Scholar

- Research which is freely available for redistribution

Submit your manuscript at www.biomedcentral.com/submit
Biomed Central 